\title{
Host-dependent variation in density of corallivorous snails (Coralliophila spp.) at Curaçao, southern Caribbean
}

\author{
Gerrit Potkamp $^{1,2}$ • Mark J. A. Vermeij ${ }^{2,3}$ - Bert W. Hoeksema ${ }^{1,4}$
}

Received: 18 June 2016 /Revised: 8 October 2016 / Accepted: 11 October 2016 /Published online: 31 October 2016

(C) The Author(s) 2016. This article is published with open access at Springerlink.com

\begin{abstract}
Snails of the genus Coralliophila (Muricidae: Coralliophilinae) are common in the Caribbean as corallivores that feed on a large range of host species. The present study concerns the distribution of two Coralliophila snails, C. caribaea and C. galea, at 5-m and 10-m depths at Curaçao (southern Caribbean), as associates of the common scleractinians Orbicella annularis and Pseudodiploria strigosa. Coralliophila galea was abundant on both host species, while $C$. caribaea was represented only by a single individual on a colony of $P$. strigosa. No significant differences in shell length were found between snails associated with $O$. annularis and P. strigosa. The distribution of C. galea on both host species deviated significantly from a random distribution. The snails were most abundant at $5-\mathrm{m}$ depth, particularly on larger colonies of $O$. annularis, with $>60 \%$ of large colonies colonized by snails, while snails were absent on small colonies. This distinction was not significant in $P$. strigosa at the same depth or in $O$. annularis at a depth of $10 \mathrm{~m}$. The results suggest that host preference should be considered in assessments of reef health in connection to damage caused by Coralliophila spp.
\end{abstract}

Communicated by R. Vonk

Bert W. Hoeksema

bert.hoeksema@naturalis.nl

1 Naturalis Biodiversity Center, PO Box 9517, 2300 RA Leiden, The Netherlands

2 Institute for Biodiversity and Ecosystem Dynamics, University of Amsterdam, Science Park 700, 1098

XH Amsterdam, The Netherlands

3 CARMABI Foundation, PO Box 2090, Piscaderabaai z/n, Willemstad, Curaçao

4 Institute of Biology Leiden, Leiden University, PO Box 9505, 2300 RA Leiden, The Netherlands
Keywords Association · Coral · Co-occurrence . Corallivory $\cdot$ Distribution $\cdot$ Coralliophilinae $\cdot$ Muricidae

\section{Introduction}

Coral reefs are amongst the most biologically diverse ecosystems in the world, providing habitats for many marine species (Reaka-Kudla 1997; Rotjan and Lewis 2008; Netchy et al. 2016). Some of the reef-dwelling species, such as corallivorous snails, consume live coral, which may contribute to the decline in coral reefs (Rotjan and Lewis 2008).

Corallivorous gastropods of the genus Coralliophila (Muricidae: Coralliophilinae) can be found at depths ranging from shallow to deep in both the Atlantic and the Indo-Pacific (Oliverio et al. 2009). A total of four shallow-water reefdwelling species of this genus are known from the Caribbean (Kosuge and Suzuki 1985; Rosenberg et al. 2009), another one from the northeastern Atlantic and the Mediterranean (Kružić et al. 2013), and ca. 20 species from the Indo-Pacific (Oliverio 2008). With these four Coralliophila species and a coral-predating heterobranch slug of the genus Berthellina (Vermeij 2010), the diversity of corallivorous snails in the Caribbean is low compared to that in the Indo-Pacific, which is consistent with earlier findings (Robertson 1970). In addition to the ca. 20 Coralliophila species mentioned above, various coral-eating gastropods have been reported from the Indo-Pacific, belonging to genera and families that are not known from the Caribbean, such as four coral-eating Drupella species (Muricidae: Ergalataxinae; Claremont et al. 2011), the nudibranch genus Phestilla, with five species (Ritson-Williams et al. 2003), and 17 corallivorous wentletrap snails of the family Epitoniidae (Gittenberger and Gittenberger 2005). For a better 
understanding of the damage inflicted by corallivorous snails, information on their choice of prey is needed, which can be inferred from the host corals on which they have been found. Many known studies have investigated the diet of Drupella snails associated with Indo-Pacific scleractinians (Boucher 1986; Turner 1994; Cumming 1999; Morton et al. 2002; Shafir et al. 2008; Schoepf et al. 2010; Al-Horani et al. 2011; Hoeksema et al. 2013; Moerland et al. 2016) and Cyphoma snails (Ovulidae: Simniinae) associated with Caribbean octocorals (Lasker and Coffroth 1988; Lasker et al. 1988; Chiappone et al. 2003; Burkepile and Hay 2007; Reijnen et al. 2010; Schärer and Nemeth 2010; Lucas et al. 2014). Snails of those genera appear to be generalists regarding their choice of host, which is in part dependent on variable host availability (Lasker and Coffroth 1988; Moerland et al. 2016). Based on a number of local studies, shallow-water Coralliophila spp. in the Indo-Pacific appear to be predominantly associated with Porites corals (Fujioka and Yamazato 1983; Schuhmacher 1993; Al-Moghrabi 1997; Oren et al. 1998; Chen et al. 2004; Raymundo et al. 2016), whereas Coralliophila snails in the Caribbean have been recorded from a wide range of host corals (Van Benthem Jutting 1927; Miller 1981; Del Monaco et al. 2010; Williams et al. 2014; Potkamp 2016).

These predatory snails are the subject of the present research and concern the two most commonly recorded Coralliophila species in the Caribbean (Miller 1981; Del Monaco et al. 2010; Potkamp 2016), i.e., C. caribaea Abbott 1958, and C. galea (Dillwyn, 1823). The latter has typically been misidentified as C. abbreviata (Lamarck, 1816) in the literature (Netchy et al. 2016; Potkamp 2016). Morphological descriptions of Caribbean Coralliophila species are given by Abbott (1958), Wells and Lalli (1977), and Potkamp (2016).

The impact of $C$. galea on coral assemblages was long thought to be minimal (Ott and Lewis 1972), but the effect of this snail on reef communities can be profound, and played a major role in the collapse of Acropora cervicornis (Lamarck, 1801) in Jamaica in 1980 after hurricane Allen (Knowlton et al. 1981, 1988, 1990; Hayes 1990a). Removal of life tissue by the snails is usually followed by algal colonization of the exposed skeleton, and such wounds appear to be difficult to heal (Brawley and Adey 1982). The host-related differences in population structure, metabolism and genetic structure of $C$. galea are well studied (Baums et al. 2003a, b; Johnston and Miller 2006; Johnston et al. 2012), but only a few studies deal with the distribution patterns of C. galea over various hosts or its prey preferences (Miller 1981; Rylaarsdam 1983; Hayes 1990a, b; Bruckner et al. 1997).

In the present study, the distribution of Coralliophila spp. over two abundant host corals, Orbicella annularis (Ellis and Solander, 1786) and Pseudodiploria strigosa
(Dana, 1846), is investigated to examine how host colony size affects the distribution of snails and how these patterns vary over the studied hosts. In particular, $O$. annularis is well known as a common host for Coralliophila spp. (Wells and Lalli 1977; Miller 1981; Del Monaco et al. 2010). At Curaçao, it was the most common host coral species, whereas $P$. strigosa ranked second (Potkamp 2016). The elkhorn coral, Acropora palmata (Lamarck, 1816), is known as a common prey of Coralliophila snails (Baums et al. 2003a; Miller 2001; Johnston et al. 2012; Bright et al. 2016). However, its abundance in Curaçao has strongly declined over the last decades (Chamberland et al. 2015), which made it unsuitable as possible host in the present study. The present study also investigates the relation between host and snail shell size, as has been reported in previous studies on other host coral species (Bruckner et al. 1997; Baums et al. 2003a; Johnston and Miller 2006).

\section{Material and methods}

Surveys for this study were conducted 12-16 March 2015 during scuba diving on the reef at the Waterfactory $\left(\mathrm{N} 12^{\circ} 06^{\prime}\right.$, W068 $\left.{ }^{\circ} 57^{\prime}\right)$, at the leeward side of the island of Curaçao, southern Caribbean. The distribution of Coralliophila spp. on Orbicella annularis was assessed at depths of $5 \mathrm{~m}$ and $10 \mathrm{~m}( \pm 1 \mathrm{~m})$ and on Pseudodiploria strigosa at a depth of $5 \mathrm{~m}( \pm 1 \mathrm{~m})$. An assessment of P. strigosa at $10 \mathrm{~m}$ was not feasible due to the low abundance of this coral species at this depth. The first 50 colonies of the host coral species encountered within the targeted depth range were examined for the number of associated snails. In the case of $P$. strigosa, a colony was defined as one spherical structure (Fig. 1a; Humann and DeLoach 2013: 140-141). For $O$. annularis, one colony was defined as a cluster of smaller columns that were still connected to one another at the base (Fig. 1b; Humann and DeLoach 2013: 128-129). The exact length and width of each of these three transects depended on the density of the targeted host species and the steepness of the reef slope.

The height and circumference of each coral colony were measured, the exact depth was noted, and colonies were photographed to prevent duplicate sampling from the same coral colonies. If present, all snails from the colony were collected in a single sampling bag per colony. At the end of each day of sampling, snails were stored in $70 \%$ ethanol. Two Coralliophila species were encountered, $C$. galea and C. caribaea, which could be distinguished by the colour of their operculum (Abbott 1958). Snails were counted per colony. Shell length, defined as the length from the tip of the apex to the tip of the aperture, was measured with digital callipers. 
Fig. 1 Examples of corals at Curaçao used in the present study. a Pseudodiploria strigosa representing a spherical colony shape. b Orbicella annularis consisting of lobes and columns
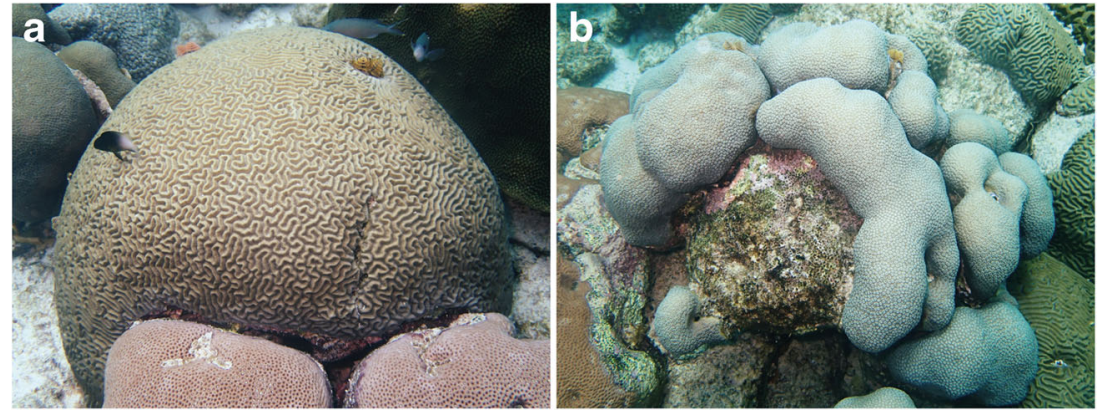

\section{Statistics}

Distributions of snails on host colonies were compared to calculate random distributions, in which all colonies have an equal chance of being colonized by snails. To calculate a random distribution, the total number of snails found on each host species (O. annularis, $n=197$; $P$. strigosa, $n=32$ ) was randomly distributed 100 times over the number of searched colonies (O. annularis, $n=100 ;$ P. strigosa, $n=50)$. Colonies were ordinally ranked based on the number of associated snails for each separate host species, where ranking number 1 was assigned to the colony with the most associated snails. The calculated distributions were averaged to obtain a random distribution per host species. Both the observed and calculated random distributions of snails were fitted against the following equation:

$n=a \times e^{-r \times b}$

where $n$ is the number of snails per colony, and $r$ is the rank of a colony based on the number of associated snails. For both species, the random distribution was compared to the observed distribution by comparing the performance of a pooled model, where parameter values were estimated for a combined data set of both the observed and random distribution, vs. a separate model where the parameter values were estimated separately for the observed and random distributions. Both models were compared using analysis of variance (ANOVA). If the difference between the random and observed distribution was significant, parameter values were compared using Welch's $t$ test.

Differences in the colonization frequency of snails (presence or absence) were tested using Fisher's exact test. For pairwise post hoc comparisons, $p$ values were adjusted using a Bonferroni correction to reduce the chances of obtaining false-positive results. Colonies were arbitrarily divided into three size classes based on their circumference. Colony height was not used, as a relatively strong positive relation was found between height and circumference for both host species (O. annularis: $R^{2}=0.65 ; p<0.0001 ;$ P. strigosa: $R^{2}=0.49$; $p<0.0001)$. Orbicella annularis corals with a circumference $\leq 35 \mathrm{~cm}$ were classified as small $(n=33)$, with a circumference $>35 \mathrm{~cm}$ and $\leq 70 \mathrm{~cm}$ as medium $(n=34)$, and circumference $>70 \mathrm{~cm}$ as large $(n=33)$. Pseudodiploria strigosa corals with a circumference $\leq 70 \mathrm{~cm}$ were classified as small $(n=16)$, with a circumference $>70 \mathrm{~cm}$ and $\leq 120 \mathrm{~cm}$ as medium $(n=16)$, and a circumference $>120 \mathrm{~cm}$ as large $(n=18)$. Poisson regressions based on quasi-likelihood models were used to model snail counts as a function of colony circumference. Analysis of covariance (ANCOVA) models were constructed to test for differences in shell length. For these, only the shells of C. galea were used.

\section{Results}

A total of 229 snails were found on 38 of 150 searched colonies (Table 1). Of these 229 snails, eight individuals were lost during collection. All snails were identified as C. galea, with the exception of one snail on a colony of $P$. strigosa, which was identified as $C$. caribaea. No colony was found with both C. galea and C. caribaea. Snails usually occurred in clusters of ca. 5-10 individuals at the edge of living coral tissue, on $O$. annularis mostly between the columns making up the colony (Fig. 2).

For both $O$. annularis and P. strigosa, the observed distribution of Coralliophila snails differed from a random distribution $(F=2644.2 ; p<0.0001$ and $F=72.0$; $p<0.0001$, respectively). Both parameters $a$ and $b$ were

Table 1 Numbers of coral colonies of Pseudodiploria strigosa $(5 \mathrm{~m}$ depth) and Orbicella annularis (5 and $10 \mathrm{~m}$ depth) with snails and the total numbers of Coralliophila galea and C. caribaea individuals found per transect

\begin{tabular}{llll}
\hline & P. strigosa & O. annularis & \\
\hline Depth (m) & 5 & 5 & 10 \\
Number of colonies & 50 & 50 & 50 \\
Colonies with snails & 10 & 24 & 4 \\
C. galea & 31 & 190 & 7 \\
C. caribaea & 1 & 0 & 0 \\
\hline
\end{tabular}


Fig. 2 a Cluster of Coralliophila galea snails wedged in between two columns of an Orbicella annularis colony. b A few $C$. galea individuals in a crevice on the surface of an $O$. annularis colony. c, d Clusters of $C$. galea inside crevices of Pseudodiploria strigosa colonies. Scale bars: $1 \mathrm{~cm}$
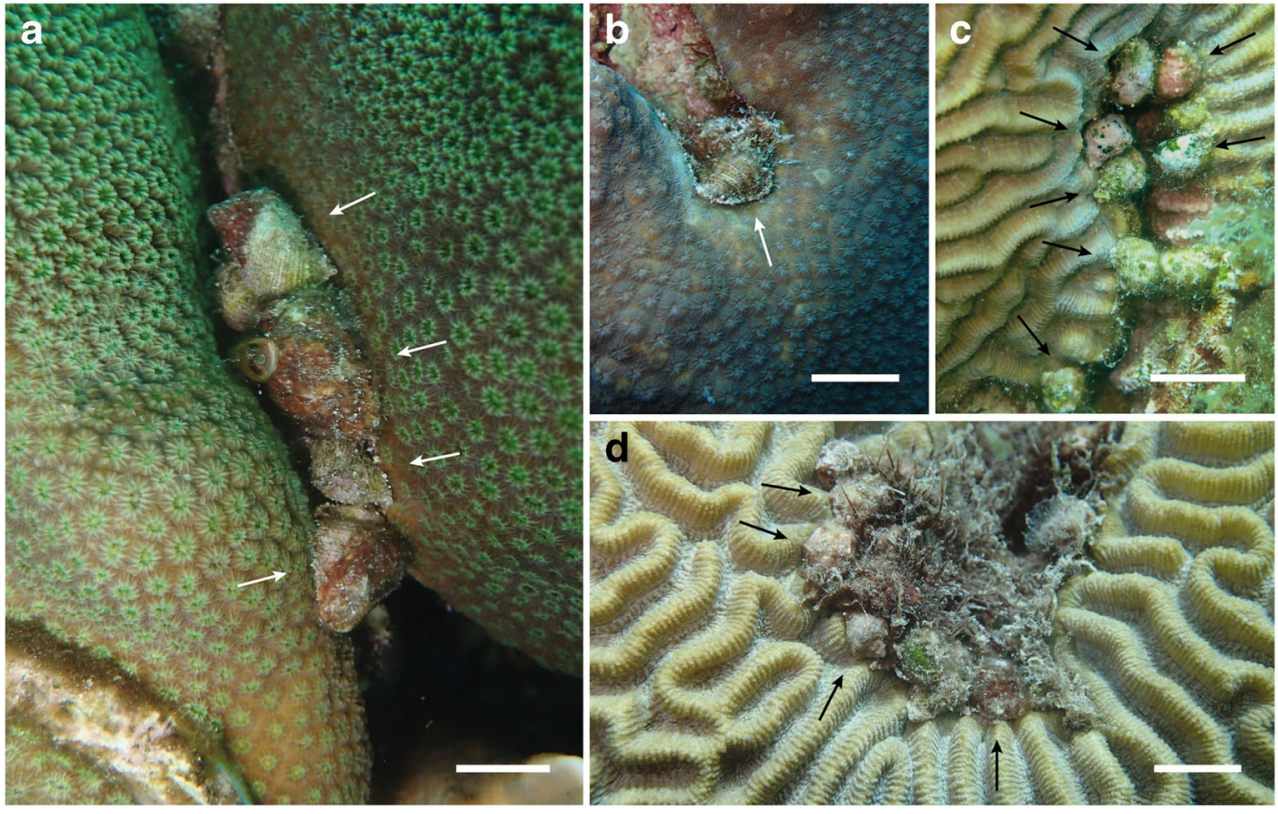

significantly different in the observed distribution compared to the random distribution in both $O$. annularis $(t=67.4$; $p<0.0001$ and $t=51.3 ; p<0.0001$, respectively) and in P. strigosa $(t=11.2 ; p<0.0001$ and $t=7.8 ; p<0.0001$, respectively [Table 2]). A higher proportion of snails was associated with only a small proportion of colonies (i.e., parameter $a$ is higher in the model of the observed distribution compared to the random distribution): for $O$. annularis, $54 \%$ of collected snails were found on only $5 \%$ of searched colonies; for P. strigosa, $63 \%$ of collected snails were found on $8 \%$ of searched colonies (observed distribution in Fig. 3). A higher proportion of colonies had no greater number of associated snails than would be expected at random. This also follows from the higher parameter $b$ in the model of the observed compared to the random distribution (Table 2; Fig. 3) and indicates that the snails show a clumped rather than random distribution over the available colonies.

The proportion of coral colonies with snails differed significantly among the three transects $(p<0.0001$; Fig. 4). $O$. annularis at 5-m depth had the highest proportion of snail-colonized colonies, with 24 of 50 colonies observed with snails, which is significantly more than both $O$. annularis at
$10 \mathrm{~m}$ (4 of 50 colonies with snails, $p<0.0001)$ and $P$. strigosa at $5 \mathrm{~m}$ (10 of 50 colonies with snails, $p=0.017$ ).

Colony size might be a factor in explaining the observed differences in proportion of snail-colonized colonies. Colony circumference differed significantly between $O$. annularis at $10 \mathrm{~m}$ and $O$. annularis at $5 \mathrm{~m}(F=14.9 ; p=0.0002$, circumference transformed with a natural logarithm to achieve normality and homogeneity of variance; Fig. 5). With all transects pooled, there were indeed significant differences between colony size classes in the proportion of colonies with snails $(p=0.0004)$. Small colonies had significantly fewer snails associated with them than either medium $(p=0.049)$ or large colonies $(p=0.0003)$. However, when considering different host species and depth on their own, this trend is only significant in colonies of Orbicella annularis at $5 \mathrm{~m}$ $(p=0.001)$. Here again, a higher proportion of small colonies were found with snails than on medium $(p=0.028)$ or large colonies ( $p=0.001$; Fig. $6 \mathrm{~b}$ ). Differences in proportion of colonies with snails between different colonies size classes were not significant in either $O$. annularis at $10 \mathrm{~m}$ or $P$. strigosa at $5 \mathrm{~m}(p=0.346$ and $p=1.0$, respectively; Fig. 6a, c).
Table 2 Estimated parameter values and standard errors of parameters $a$ and $b$ of the exponential function fitted to the observed and calculated random distributions of snails on host colonies of Orbicella annularis and Pseudodiploria strigosa

\begin{tabular}{|c|c|c|c|c|c|}
\hline \multirow[b]{2}{*}{ Host species } & \multirow[b]{2}{*}{ Distribution } & \multicolumn{2}{|c|}{ Parameter $a$} & \multicolumn{2}{|c|}{ Parameter $b$} \\
\hline & & Estimated & Standard error & Estimated & Standard error \\
\hline \multirow[t]{2}{*}{ P. strigosa } & Observed & 7.65 & 0.37 & 0.195 & 0.012 \\
\hline & Random & 2.91 & 0.21 & 0.082 & 0.008 \\
\hline \multirow[t]{2}{*}{ O. annularis } & Observed & 32.37 & 0.38 & 0.153 & 0.002 \\
\hline & Random & 5.30 & 0.14 & 0.024 & 0.001 \\
\hline
\end{tabular}



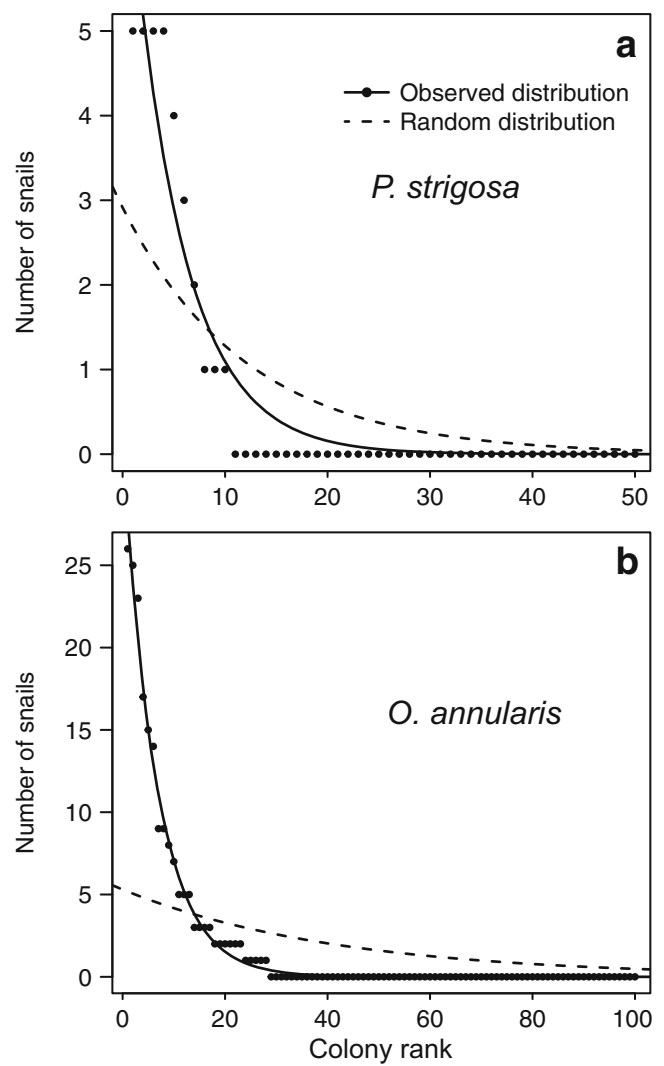

Fig. 3 Comparison of observed distribution with calculated random distribution for snails on Pseudodiploria strigosa (a) and Orbicella annularis (b). Individual observations are plotted as dots; curves represent the fitted models. For estimated parameter values, see Table 2

Colony size might also play a role in the number of snails that can be sustained on a singly colony. On $O$. annularis colonies (both 5-m and 10-m transects pooled), larger colonies sustained significantly more snails than smaller colonies $(p<0.0001$; Fig. 7a). No significant relation was found between $P$. strigosa colony size and number of snails on a single colony ( $p=0.288$; Fig. $7 b$ ), which implies that larger colonies

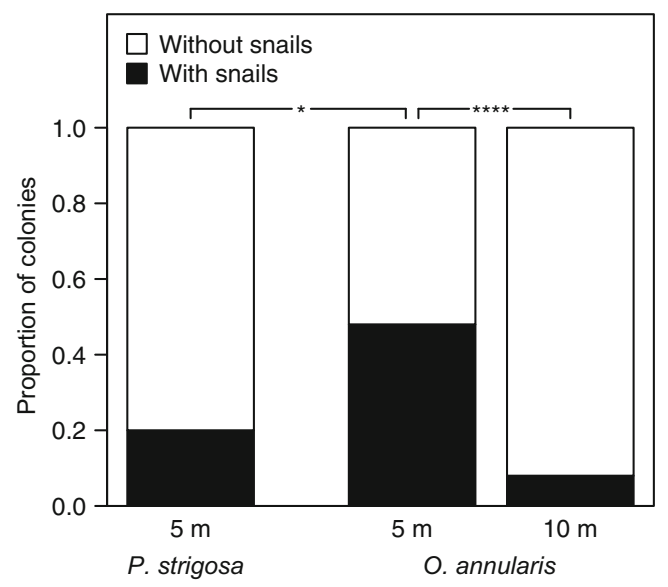

Fig. 4 Proportion of colonized host colonies of Pseudodiploria strigosa at a depth of $5 \mathrm{~m}$, and Orbicella annularis at depths of 5 and $10 \mathrm{~m}$. Significant differences: $* p<0.05 ; * * * p<0.0001$

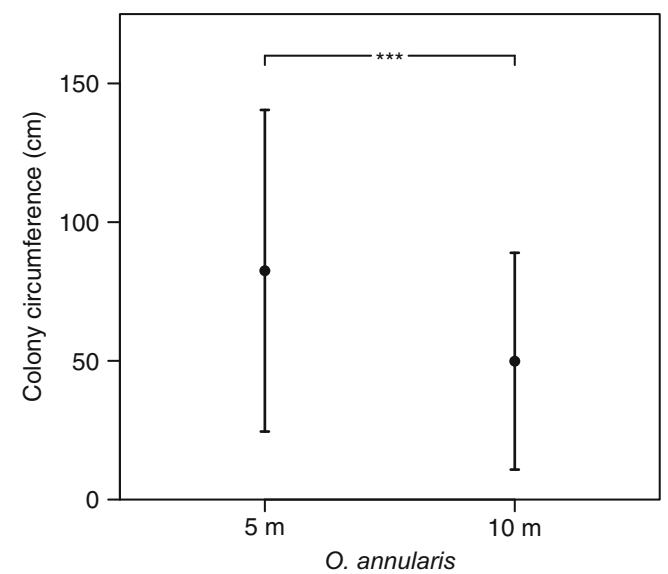

Fig. 5 Mean circumference of all sampled colonies of Orbicella annularis at depths of 5 and $10 \mathrm{~m}$. Error bars show standard deviations. Significant differences: $* * * p<0.001$

of $P$. strigosa do not have a greater number of snails feeding on them.

The shell length of $C$. galea ranged from 6.2 to $24.6 \mathrm{~mm}$, plus one outlier at $32.2 \mathrm{~mm}$ (associated with a colony of $P$. strigosa); the single $C$. caribaea had a shell length of $15.5 \mathrm{~mm}$. Snails associated with $O$. annularis at both depths were pooled, as only a few snails were found on $O$. annularis at $10 \mathrm{~m}$. An ANCOVA model was constructed for $C$. galea shell length, including the following factors: host species, an interaction effect between colony circumference and host species, and an interaction between number of associated snails per colony and host species (neither the colony circumference nor number of associated snails was included in the model as a single factor on its own, as differences, for example, in colony morphology may not allow for direct comparisons of these factors between host species). Of these factors, only host species contributed significantly to shell length $(F=5.7 ; p=$ 0.018; neither the interaction between number of associated snails and host species $(F=2.8 ; p=0.062)$ nor the interaction between colony circumference $(F=0.9 ; \mathrm{p}=0.425)$ was significant. However, the one outlier contributed disproportionally to the significance of the host species factor. Without the outlier, host species was no longer significant $(F=2.7 ; p=$ 0.105 ). Therefore, no differences in shell length could be confidently detected within the data set (Fig. 8).

\section{Discussion}

Coralliophila galea was most abundant on both common coral host species, Orbicella annularis and Pseudodiploria strigosa, whereas $C$. caribaea was represented by only a single specimen on the latter. The same pattern, in which $C$. galea was more common on the same hosts compared to C. caribaea, was observed on other reefs along the coast of Curaçao (GP, personal observation), as well as in other 

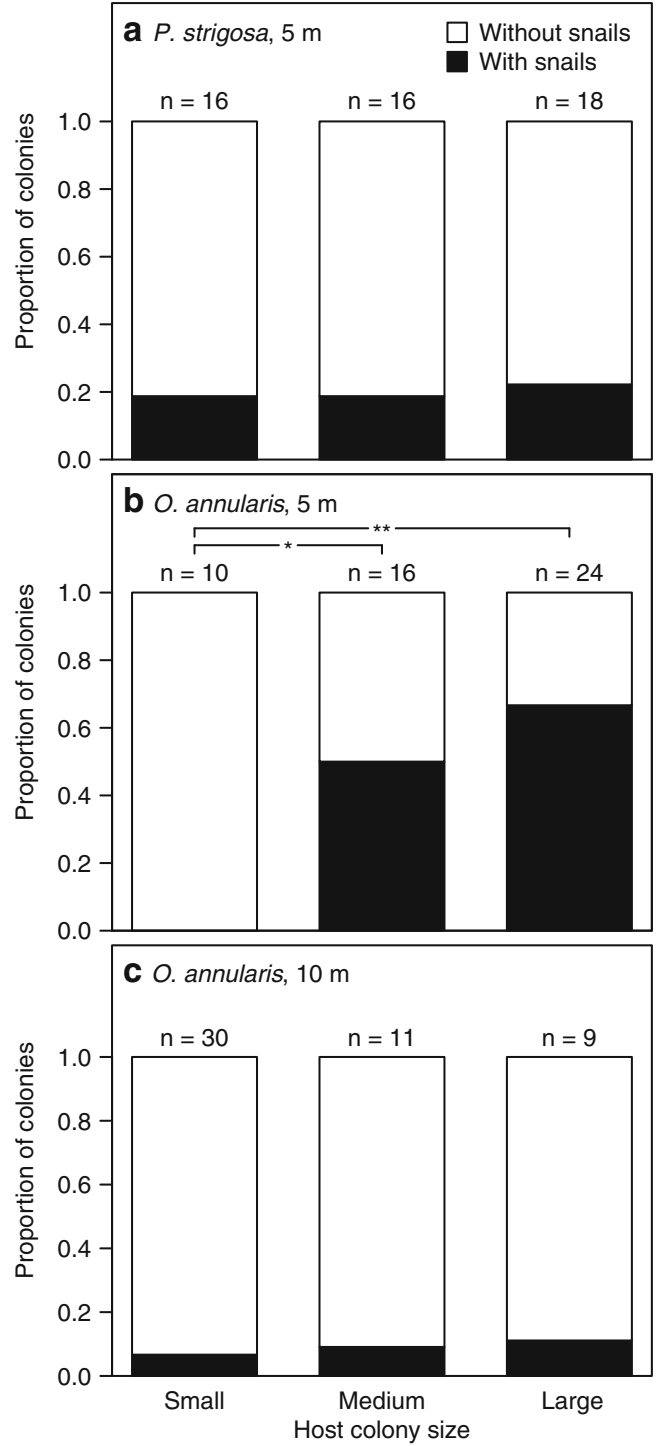

Fig. 6 Proportion of colonized host colonies of Pseudodiploria strigosa at a depth of $5 \mathrm{~m}$ (a) and Orbicella annularis at depths of $5 \mathrm{~m}$ (b) and $10 \mathrm{~m}(\mathbf{c})$, separated by colony size class. Significant differences: $* p<0.05 ; * * * * p 0.0001$

Caribbean localities (Miller 1981; Del Monaco et al. 2010). Therefore, the predation impact of C. caribaea on both $O$. annularis and $P$. strigosa can be considered negligible. There is no indication of competition between the two Coralliophila spp. for these two host coral species, and it is unclear how the apparent partitioning in prey selection between the two snail species is maintained (Miller 1981).

In the present study, $25 \%$ of all searched colonies were found to have associated Coralliophila snails, whereas a Puerto Rican study reported that $9 \%$ of coral colonies belonging to seven species were observed with snails (Bruckner et al. 1997). The variation in occupancy appears to be host-related, since in Panama, $64 \%$ of Orbicella colonies, $13 \%$ of Agaricia tenuifolia Dana, 1848 , and $10 \%$ of Acropora cervicornis were found
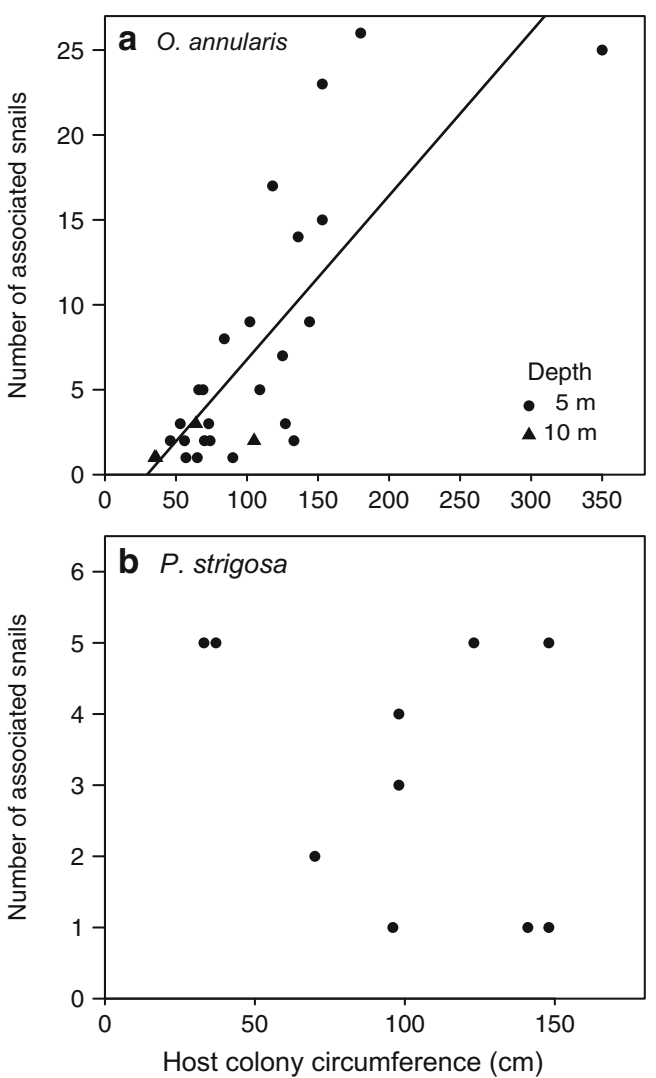

Fig. 7 Relation between the number of snails per host colony and the host colony circumference for both Orbicella annularis (a) and Pseudodiploria strigosa (b). Only the regression for $O$. annularis is shown $(p<0.0001)$; the regression for $P$. strigosa was not significant

with snails (Hayes 1990b). The observed difference in Coralliophila colonization between $O$. annularis and $P$. strigosa in the present study may depend on the colony morphology of the hosts and on their depth. Corals of both species form massive colonies, but these differ in height and complexity. Among coral colonies of similar circumference, those of $O$. annularis show a lobate shape, with much space between the columns and

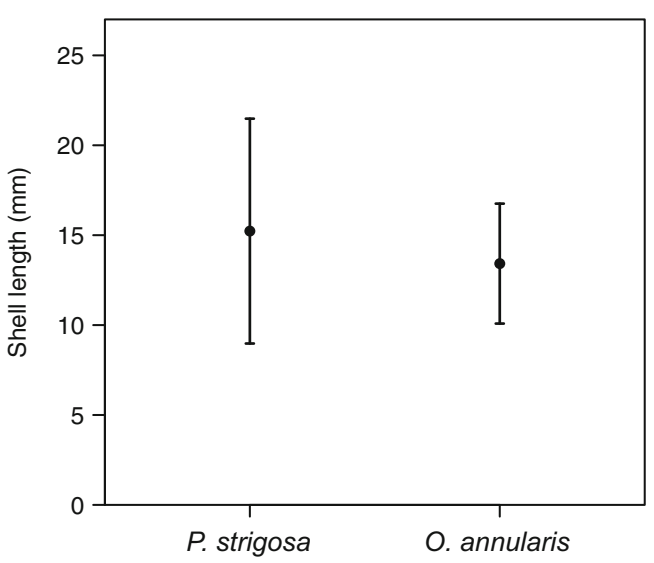

Fig. 8 Shell length of Coralliophila galea on Pseudodiploria strigosa and Orbicella annularis. Error bars show the standard deviations 
relatively high total surface area, whereas those of P. strigosa are more dome-shaped, with less surface area. Lobate and columnar corals possess a relatively long borderline between living and dead coral tissue around the columns where Coralliophila snails are usually found. Little information is available regarding the dominant position of Coralliophila snails on their hosts, but there appears to be a preference for the fringes around the base of coral colonies (Miller 1981), while the present study and various others (Ward 1965; Ott and Lewis 1972) point to the boundary between dead and live coral tissue.

The distribution of snails was not random over the available hosts colonies for either of the studied host species. The number of snails per host was positively related to host coral size, which is consistent with research on corallivorous Drupella snails in the Indo-Pacific (Cumming 2009; Schoepf et al. 2010; Moerland et al. 2016). Intuitively, larger host colonies (with increasing age) have more likely become colonized by snails over time than smaller and younger host colonies, and also offer more available space for larger snail aggregations.

The extent to which snails are able to actively choose their prey is an important factor when considering distribution patterns. Experiments by Rylaarsdam (1983) and Hayes (1990a) showed that adult snails may have some preference for certain host species. Additionally, microcosm experiments showed that snails, after being displaced from colonies of A. palmata, returned to colonies of the same species, ignoring colonies of other host species (Brawley and Adey 1982). These findings suggest that snails are able to actively select their host colony, at least during the adult stage. No data are available on whether active selection of prey is already present during the larval stage or during egg deposition as seen in parasitic snails of the family Epitoniidae (Gittenberger and Hoeksema 2013) and corallivorous snails of the genera Pseudosimnia (Priori et al. 2015) and Drupella (Sam et al. 2016).

Differences in predation pressure may also explain variation in the number of snails per host species. Snails on colonies with a dome shape ( $P$. strigosa) may be more exposed to attacks from their own predators than those in between the columns of a lobate coral colony (O. annularis), which may offer shelter (Fig. 2a). Unfortunately, information on predators feeding on Coralliophila spp. is limited to anecdotal evidence. Possible predators of $C$. galea include a snapping shrimp, a carnivorous snail, the Caribbean spiny lobster, puffer fish, hogfish, filefish and octopuses (Goldberg 1971; Baums et al. 2003a; Sharp and Delgado 2015).

No connections were observed between shell length and snail group size or host colony circumference. Such a connection might indicate the existence of intraspecific competition between snails, as larger groups of snails or snails on smaller colonies might have less food. A negative correlation between body size and population size is well known in land snails (e.g., Williamson et al. 1976; Cameron and Carter 1979). Host-specific size clustering of Coralliophila galea has been observed for different host species (Hayes 1990b; Bruckner et al. 1997; Baums et al. 2003a; Johnston and Miller 2006). However, no significant differences in shell length were found between snails associated with $O$. annularis and $P$. strigosa. In the present study, the sample sizes of colonies with specific size classes were unbalanced for the two $O$. annularis transects (Fig. 6). As this may affect the power of the statistical tests, future studies investigating the effect of host colony size on snail distribution, specifically sampling certain colony size classes, could overcome this problem, and may help provide a better understanding of the relationship between these two variables.

Most previous research on corallivorous gastropods on Caribbean reefs have focused on a few hosts such as Acropora spp. and Orbicella spp. (Miller 2001; Baums et al. 2003a, b; Johnston and Miller 2006; Bright et al. 2016), or have grouped many host species together (Bruckner et al. 1997). However, the host range on which Caribbean Coralliophila spp. can be found is large, spanning multiple orders within the class Anthozoa (Miller 1981). The present results indicate that patterns of distribution differ between two host coral species, and therefore that patterns found for one host species cannot be extrapolated to a whole reef coral assemblage.

To better understand how corallivory by Coralliophila spp. affects Caribbean coral faunas, it will be important for future surveys to cover a wide range of host species, including less common ones. It is also relevant to include the second most common Coralliophila species in the Caribbean, i.e., C. caribaea. The effect of C. caribaea on $O$. annularis and P. strigosa was negligible in the present study, but C. caribaea is common, for example, on Porites spp. and various octocoral species (Miller 1981; Del Monaco et al. 2010). Octocorals are an important part of Caribbean reef communities (Sánchez et al. 1998; Abeytia et al. 2013; Velásquez and Sánchez 2015; Edmunds et al. 2016). Future research on Coralliophila spp. as predators should therefore also focus more on octocorals as prey, which will provide a more comprehensive understanding of the impact of corallivory on coral assemblages.

Acknowledgments The first author would like to thank Thijs Böhm and Dasha Wels for being dive buddies and great company during the fieldwork. The first author is grateful for the financial support from the Jan Joost ter Pelkwijk Fund and the Alida M. Buitendijk Fund and for the hospitality and assistance from the staff of CARMABI (Caribbean Research and Management of Biodiversity). We thank two anonymous reviewers for their constructive comments. 
Open Access This article is distributed under the terms of the Creative Commons Attribution 4.0 International License (http:// creativecommons.org/licenses/by/4.0/), which permits unrestricted use, distribution, and reproduction in any medium, provided you give appropriate credit to the original author(s) and the source, provide a link to the Creative Commons license, and indicate if changes were made.

\section{References}

Abbott RT (1958) Marine mollusks of Grand Cayman Island, British West Indies. Monogr Acad Nat Sci Phila 11:1-138

Abeytia R, Guzmán HM, Breedy O (2013) Species composition and bathymetric distribution of gorgonians (Anthozoa: Octocorallia) on the Southern Mexican Pacific coast. Rev Biol Trop 61:1157-1166

Al-Horani FA, Hamdi M, Al-Rousan SA (2011) Prey selection and feeding rates of Drupella cornus (Gastropoda: Muricidae) on corals from the Jordanian coast of the Gulf of Aqaba, Red Sea. Jordan J Biol Sci 4:191-198

Al-Moghrabi SM (1997) Bathymetric distribution of Drupella cornus and Coralliophila neritoidea in the Gulf of Aqaba (Jordan). Proc 8th Int Coral Reef Symp 2:1345-1350

Baums I, Miller M, Szmant A (2003a) Ecology of a corallivorous gastropod, Coralliophila abbreviata, on two scleractinian hosts. I: Population structure of snails and corals. Mar Biol 142:10831091. doi:10.1007/s00227-003-1024-9

Baums I, Miller M, Szmant A (2003b) Ecology of a corallivorous gastropod, Coralliophila abbreviata, on two scleractinian hosts. II. Feeding, respiration and growth. Mar Biol 142:1093-1101. doi:10.1007/s00227-003-1053-4

Boucher LM (1986) Coral predation by muricid gastropods of the genus Drupella at Enewetak, Marshall Islands. Bull Mar Sci 38:9-11

Brawley SH, Adey WH (1982) Coralliophila abbreviata: a significant corallivore! Bull Mar Sci 32:595-599

Bright AJ, Rogers CS, Brandt ME, Muller E, Smith TB (2016) Disease prevalence and snail predation associated with swell-generated damage on the threatened coral, Acropora palmata (Lamarck). Front Mar Sci 3:77. doi:10.3389/fmars.2016.00077

Bruckner RJ, Bruckner AW, Williams EH (1997) Life history strategies of Coralliophila abbreviata Lamarck (Gastropoda: Coralliophilidae) on the southwest coast of Puerto Rico Proc 8th Int Coral Reef Symp 1:627-632

Burkepile DE, Hay ME (2007) Predator release of the gastropod Cyphoma gibbosum increases predation on gorgonian corals. Oecologia 154:167-173. doi:10.1007/s00442-007-0801-4

Cameron RAD, Carter MA (1979) Intra- and interspecific effects of population density on growth and activity in some helicid land snails (Gastropoda: Pulmonata). J Anim Ecol 48:237-246. doi:10.2307 14111

Chamberland VF, Vermeij MJ, Brittsan M, Carl M, Schick M, Snowden S, Petersen D (2015) Restoration of critically endangered elkhorn coral (Acropora palmata) populations using larvae reared from wild-caught gametes. Global Ecol Conserv 4:526-537. doi:10.1016/j.gecco.2015.10.005

Chen MH, Soong K, Tsai ML (2004) Host effect on size structure and timing of sex change in the coral-inhabiting snail Coralliophila violacea. Mar Biol 144:287-293. doi:10.1007/s00227-003-1204-7

Chiappone M, Dienes H, Swanson DW, Miller SL (2003) Density and gorgonian host-occupation patterns by flamingo tongue snails (Cyphoma gibbosum) in the Florida Keys. Caribb J Sci 39:116-127

Claremont M, Reid DG, Williams ST (2011) Evolution of corallivory in the gastropod genus Drupella. Coral Reefs 30:977-990. doi:10.1007/s00338-011-0788-5
Cumming RL (1999) Predation on reef-building corals: multiscale variation in the density of three corallivorous gastropods, Drupella spp. Coral Reefs 18:147-157. doi:10.1007/s003380050170

Cumming RL (2009) Population outbreaks and large aggregations of Drupella on the Great Barrier Reef. GBRMPA Res Publ 96:1-26

Del Monaco C, Villamizar E, Narciso S (2010) Selectividad de presas de Coralliophila abbreviata y C. caribaea en arrecifes coralinos del Parque Nacional Morrocoy, Venezuela: una aproximacion experimental. Lat Am J Aquat Res 38:57-70. doi:10.3856/vol38-issue1-fulltext-6

Edmunds PJ, Tsounis G, Lasker HR (2016) Differential distribution of octocorals and scleractinians around St. John and St. Thomas, US Virgin Islands. Hydrobiologia 767:347-360. doi:10.1007/s10750$015-2555-Z$

Fujioka Y, Yamazato K (1983) Host selection of some Okinawan coral associated gastropods belonging to the genera Drupella, Coralliophila and Quoyula. Galaxea 2:59-73

Gittenberger A, Gittenberger E (2005) A hitherto unnoticed adaptive radiation: epitoniid species (Gastropoda: Epitoniidae) associated with corals (Scleractinia). Contrib Zool 74:125-203

Gittenberger A, Hoeksema BW (2013) Habitat preferences of coralassociated wentletrap snails (Gastropoda: Epitoniidae). Contrib Zool 82:1-25

Goldberg WM (1971) A note on the feeding behavior of the snapping shrimp Synalpheus fritzmuelleri Coutière (Decapoda, Alpheidae). Crustaceana 21:318-320. doi:10.1163/156854071X00652

Hayes JA (1990a) Prey preference in a Caribbean corallivore, Coralliophila abbreviata (Lamarck) (Gastropoda, Coralliophilidae). Bull Mar Sci 47:557-560

Hayes JA (1990b) Distribution, movement and impact of the corallivorous gastropod Coralliophila abbreviata (Lamarck) on a Panamánian patch reef. J Exp Mar Biol Ecol 142:25-42. doi:10.1016/0022-0981(90)90135-Y

Hoeksema BW, Scott C, True JD (2013) Dietary shift in corallivorous Drupella snails following a major bleaching event at Koh Tao, Gulf of Thailand. Coral Reefs 32:423-428. doi:10.1007/s00338-012-1005-x

Humann P, DeLoach N (2013) Reef coral identification: Florida, Caribbean, Bahamas, 3rd edn. New World Publications, Jacksonville

Johnston L, Miller MW (2006) Variation in life-history traits of the corallivorous gastropod Coralliophila abbreviata on three coral hosts. Mar Biol 150:1215-1225. doi:10.1007/s00227-006-0422-1

Johnston L, Miller MW, Baums IB (2012) Assessment of host-associated genetic differentiation among phenotypically divergent populations of a coral-eating gastropod across the Caribbean. PLoS One 7(11): e47630. doi:10.1371/journal.pone.0047630

Knowlton N, Lang JC, Keller BD (1988) Fates of staghorn coral isolates on hurricane-damaged reefs in Jamaica: The role of predators. Proc 6th Int Coral Reef Symp 2:83-88

Knowlton N, Lang JC, Keller BD (1990) Case study of natural population collapse: Post-hurricane predation on Jamaican staghorn corals. Smithson Contrib Mar Sci 31:1-25. doi:10.5479/si.01960768.31.1

Knowlton N, Lang JC, Rooney MC, Clifford P (1981) Evidence for delayed mortality in hurricane-damaged Jamaican staghorn corals. Nature 294:251-252. doi:10.1038/294251a0

Kosuge S, Suzuki M (1985) Illustrated catalogue of Latiaxis and its related groups, family Coralliophilidae. Institute of Malacology of Tokyo, Special Publication

Kružić P, Sršen P, Cetinić K, Zavodnik D (2013) Coral tissue mortality of the coral Cladocora caespitosa caused by gastropod Coralliophila meyendorffi in the Mljet National Park (eastern Adriatic Sea). J Mar Biol Ass UK 93:2101-2108. doi:10.1017/S0025315413000878

Lasker HR, Coffroth MA (1988) Temporal and spatial variability among grazers: variability in the distribution of the gastropod Cyphoma gibbosum on octocorals. Mar Ecol Prog Ser 43:285-295

Lasker HR, Coffroth MA, Fitzgerald LM (1988) Foraging patterns of Cyphoma gibbosum on octocorals: the roles of host choice and feeding preference. Biol Bull 174:254-266. doi:10.2307/1541952 
Lucas MQ, Rodríguez LR, Sanabria DJ, Weil E (2014) Natural prey preferences and spatial variability of predation pressure by Cyphoma gibbosum (Mollusca: gastropoda) on octocoral communities off La Parguera, Puerto Rico. Int Scholar Res Not 2014:742387. doi: $10.1155 / 2014 / 742387$

Miller A (1981) Cnidarian prey of the snails Coralliophila abbreviata and C. caribaea (Gastropoda: Muricidae) in Discovery Bay, Jamaica. Bull Mar Sci 31:932-934

Miller MW (2001) Corallivorous snail removal: evaluation of impact on Acropora palmata. Coral Reefs 19:293-295. doi:10.1007 /PL00006963

Moerland MS, Scott CM, Hoeksema BW (2016) Prey selection of corallivorous muricids at Koh Tao (Gulf of Thailand) four years after a major coral bleaching event. Contrib Zool 85:291-310

Morton B, Blackmore G, Kwok CT (2002) Corallivory and prey choice by Drupella rugosa (Gastropoda: Muricidae) in Hong Kong. J Molluscan Stud 68:217-223. doi:10.1093/mollus/68.3.217

Netchy K, Hallock P, Lunz KS, Daly KL (2016) Epibenthic mobile invertebrate diversity organized by coral habitat in Florida. Mar Biodivers 46:451-463. doi:10.1007/s12526-015-0388-7

Oliverio M (2008) Coralliophilinae (Neogastropoda: Muricidae) from the southwest Pacific. In: Héros V, Cowie RH, Bouchet P (eds) Tropical Deep-Sea Benthos 25. Mém Mus Natnl Hist Nat 196:481-585

Oliverio M, Barco A, Richter A, Modica MV (2009) The coralliophiline (Gastropoda: Muricidae) radiation: Repeated colonizations of the deep sea? Nautilus 123:113-120

Oren U, Brickner I, Loya Y (1998) Prudent sessile feeding by the corallivore snail, Coralliophila violacea on coral energy sinks. Proc R Soc Lond B 265:2043-2050. doi:10.1098/rspb.1998.0538

Ott B, Lewis JB (1972) The importance of the gastropod Coralliophila abbreviata (Lamarck) and the polychaete Hermodice carunculata (Pallas) as coral reef predators. Can J Zool 50:1651-1656. doi:10.1139/z72-217

Potkamp G (2016) Host-related divergence in Coralliophila spp. at Curaçao. MSc thesis, University of Amsterdam

Priori C, Erra F, Angiolillo M, Santangelo G (2015) Effects of gastropod predation on the reproductive output of an overexploited deep octocoral. Coral Reefs 34:59-63. doi:10.1007/s00338-014-1223-5

Raymundo LJ, Work TM, Miller RL, Lozada-Misa PL (2016) Effects of Coralliophila violacea on tissue loss in the scleractinian corals Porites spp. depend on host response. Dis Aquat Org 119:75-83. doi:10.3354/dao02982

Reaka-Kudla ML (1997) The global biodiversity of coral reefs: a comparision with rain forests. In: Reaka-Kudla ML, Wilson DE, Wilson EO (eds) Biodiversity II: Understanding and protecting our biological resources. Joseph Henry Press, Washington DC, pp 83-108

Reijnen BT, Hoeksema BW, Gittenberger E (2010) Host specificity and phylogenetic relationships among Atlantic Ovulidae (Mollusca: Gastropoda). Contrib Zool 79:69-78

Ritson-Williams R, Shjegstad S, Paul V (2003) Host specificity of four corallivorous Phestilla nudibranchs (Gastropoda: Opisthobranchia). Mar Ecol Prog Ser 255:207-218. doi:10.3354/meps 255207

Robertson R (1970) Review of the predators and parasites of stony corals, with special reference to symbiotic prosobranch gastropods. Pac Sci $24: 43-54$
Rosenberg G, Moretzsohn F, García EF (2009) Gastropoda (Mollusca) of the Gulf of Mexico. In: Felder DL, Camp DK (eds) Gulf of Mexico - Origins, Waters and Biota. Volume 1, Biodiversity. Texas A\&M University Press, College Station, Texas, pp 579-699

Rotjan RD, Lewis SM (2008) Impact of coral predators on tropical reefs. Mar Ecol Prog Ser 367:73-91. doi:10.3354/meps07531

Rylaarsdam KW (1983) Life histories and abundance patterns of colonial corals on Jamaican reefs. Mar Ecol Prog Ser 13:249-260

Sam SQ, Kikuzawa YP, Taira D, Ng CSL, Toh TC, Chou LM (2016) First observation of Drupella rugosa egg capsules on scleractinian coral Pocillopora damicornis. Bull Mar Sci 92:353-354. doi:10.5343 /bms.2016.1062

Sánchez JA, Zea S, Díaz JM (1998) Patterns of octocoral and black coral distribution in the oceanic barrier reef-complex of Providencia island, southwestern Caribbean. Caribb J Sci 34:250-264. doi:10.1007/s00227-003-1018-7

Schärer MT, Nemeth MI (2010) Mass mortality of gorgonians due to a Cyphoma gibbosum (Linnaeus) population outbreak at Mona Island, Puerto Rico. Coral Reefs 29:533. doi:10.1007/s00338-010-0598-1

Schoepf V, Herler J, Zuschin M (2010) Microhabitat use and prey selection of the coral-feeding snail Drupella cornus in the Northern Red Sea. Hydrobiologia 641:45-57. doi:10.1007/s10750-009-0053-x

Schuhmacher H (1993) Impact of some corallivorous snails on stony corals in the Red Sea. Proc. 7th Int Coral Reef Symp 2:840-846

Shafir S, Gar O, Rinkevich B (2008) A Drupella cornus outbreak in the northern Gulf of Eliat and changes in coral prey. Coral Reefs 27:379. doi: 10.1007/s00338-008-0353-z

Sharp WC, Delgado GA (2015) Predator-prey interactions between the corallivorous snail Coralliophila abbreviata and the carnivorous deltoid rock snail Thais deltoidea. Biol Bull 229:129-133

Turner SJ (1994) Spatial variability in the abundance of the corallivorous gastropod Drupella cornus. Coral Reefs 13:41-48. doi:10.1007 /BF00426434

Van Benthem Jutting T (1927) Marine molluscs of the island of Curaçao. Bijdr Dierk 25:1-36

Velásquez J, Sánchez JA (2015) Octocoral species assembly and coexistence in Caribbean coral reefs. PLoS ONE 10(7):e0129609. doi:10.1371/journal.pone.0129609

Vermeij MJA (2010) First observation of a nocturnal nudibranch feeding on Caribbean corals. Coral Reefs 29:1047. doi:10.1007/s00338010-0685-3

Ward J (1965) The digestive tract and its relation to feeding habits in the stenoglossan prosobranch Coralliophila abbreviata (Lamark). Can J Zool 43:447-464

Wells FE, Lalli CM (1977) Reproduction and brood protection in the Caribbean gastropods Coralliophila abbreviata and C. caribaea. J Moll Stud 43:79-87

Williams DE, Miller MW, Bright AJ, Cameron CM (2014) Removal of corallivorous snails as a proactive tool for the conservation of acroporid corals. Peer J 2:e680

Williamson P, Cameron RAD, Carter MA (1976) Population density affecting adult shell size of snail Cepaea nemoralis L. Nature 263: 496-497. doi:10.1038/263496b0 